Hazel plantation planning using GIS and multicriteria decision analysis

Planiranje nasada lijeske uporabom GIS-a i multikriterijske analize

Plaščak, I., Jurišić, M., Radočaj, D., Barač, Ž., Glavaš, J.

Poljoprivreda/Agriculture

ISSN: 1848-8080 (Online)

ISSN: 1330-7142 (Print)

$\underline{\text { http://dx.doi.org/10.18047/poljo.25.2.11 }}$

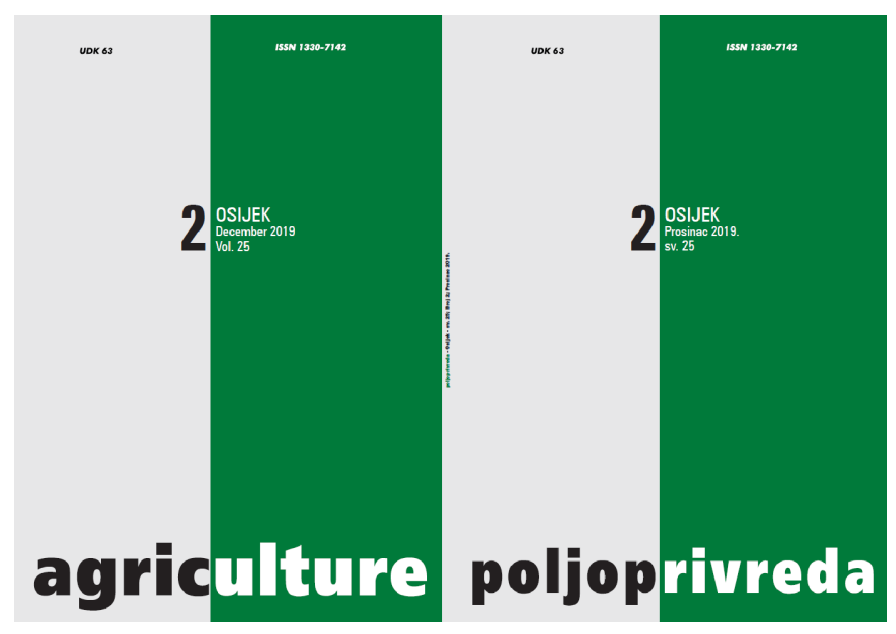

Fakultet agrobiotehničkih znanosti Osijek, Poljoprivredni institut Osijek

Faculty of Agrobiotechnical Sciences Osijek, Agricultural Institute Osijek 
ISSN $1330-7142$

$U D K=681.518 .3: 582.622 .4$

DOI: 10.18047/poljo.25.2.11

\title{
HAZEL PLANTATION PLANNING USING GIS AND MULTICRITERIA DECISION ANALYSIS
}

\author{
Plaščak, I.(1), Jurišić, M. ${ }^{(1)}$, Radočaj, D. ${ }^{(1)}$, Barač, Ž. ${ }^{(1)}$, Glavaš, J.(2)
}

Preliminary communication

Prethodno priopćenje

\begin{abstract}
SUMMARY
Spatial and environmental conditions on the agricultural land are invariable components and any plantation planning should take them into consideration. The conducted research presented methodology for suitability calculation of hazel plantations based on multicriteria analysis, performed in Vukovar-Srijem County. Nine criteria representing topographic, climate, pedology and infrastructure properties were modelled in GIS environment. Values of created layers were standardized using stepwise standardization and their respective weights were calculated by Analytical Hierarchical Process. These values were integrated using weighted linear combination, resulting with suitability values. The surrounding area of the City of llok had the highest suitability for hazel plantation in the studied locality, with maximum suitability 4.1 out of 5.0. Suitability was visualized on a thematic map, which enables farmers to interpret the data.
\end{abstract}

Keywords: multicriteria analysis, GIS, thematic map, AHP, hazel

\section{INTRODUCTION}

Agricultural land is a stationary component on which spatial and environmental conditions cannot be influenced, like topography and climate (Lake et al., 2008). A farmer can influence how and when to implement agrotechnical measures on agricultural land in order to maximise its potential. Advancements in Geographic Information System (GIS), Global Navigation Satellite System (GNSS) and remote sensing enabled the creation and analysis of spatial data for agricultural purposes (Seelan et al., 2003; Jurišić and Plaščak, 2009; Jurišić et al., 2018). One of the most notable integrations of these technologies in agriculture is by calculating cultivation suitability using multicriteria decision analysis (Hayashi, 2000). Suitability layers are visualized on thematic maps, which enable interpretation of analysed spatial data with only elemental knowledge (Jurišić et al., 2013a; Jurišić et al., 2013b). Such procedure enables farmers to determine the most suitable area for cultivation of chosen culture, especially if the individual decides to buy land and establish or expand agricultural production. Multicriteria analysis for estimation of agricultural land suitability has been a subject of research in almost all parts of the world, primarily in areas with limited natural resources. Kihoro et al. (2013) applied a multicriteria analysis for rice suitability in Kenya, based on soil and climate criteria. A similar process was applied for wheat suitability in India by Sarkar et al. (2012) in order to maximize available soil resources, which generally possessed inadequate irrigation system and soil depth. Musakwa (2017) conducted an extensive multicriteria analysis for agricultural land reform in South Africa, having 15 criteria sorted in three criteria groups representing environmental, climatic and socio-economic criteria. Multicriteria analysis in agriculture is currently not developed as a recognizable procedure for calculation of land suitability in Croatia. However, variants of spatial modelling for suitability estimation in agriculture were used extensively in the eastern Croatia during the last decade (Vukadinović et al., 2011; Bogunović et al., 2016).

This paper presents a methodology for evaluation of available sites for hazel plantations establishment. The study also covers the application of multicriteria analysis in the Vukovar-Srijem County in Croatia, with a suitability thematic map as a final result.

(1) Assoc. Prof. Ivan Plaščak, Prof. Dr. Mladen Jurišić (mjurisic@fazos. hr), M.Sc. Dorijan Radočaj, M.Sc. Željko Barač - Josip Juraj Strossmayer University of Osijek, Faculty of Agrobiotechnical Sciences Osijek, Vladimira Preloga 1, 31000 Osijek, Croatia, (2) Assoc. Prof. Jerko Glavaš - Josip Juraj Strossmayer University of Osijek, Faculty of Economics in Osijek, Trg Lj. Gaja 7, 31000 Osijek, Croatia 


\section{MATERIAL AND METHODS}

The study area is the Vukovar-Srijem County, a 2448 $\mathrm{km}^{2}$ area located in the Eastern Croatia. Agricultural land covers $1497 \mathrm{~km}^{2}$ of the County area, of which $1.72 \%$ (26 $\mathrm{km}^{2}$ ) are orchards (Vukovar-Srijem County, 2018). There is a long-standing trend of investing in permanent crops in the County, among which a hazel has a significant place. According to County development strategies (VUSZ, 2019), the number of hazel plantations has been continuously increasing during the past ten years (2009-2019). Furthermore, an energy efficiency study from 2017 recommends agricultural production as one of the primary activities for sustainable economic development in the County, due to favourable soil features, annual precipitation schedule and mild continental climate (Vukovar-Srijem County, 2017).

The process of performing a multicriteria decision analysis in this study consists of deciding on the analysis subject, determining the criteria, modelling of GIS layers, layer values standardization, computation of factor weights, suitability calculation and result analysis. Criteria were defined covering relevant spatial characteristics cultivation of hazel which can be modelled in GIS. It was then separated to factors and constraints, due to the need to determine criteria that shows cultivation suitability to some extent and Boolean criteria indicating a distinctive possibility or inability to establish a plantation. The selected criteria sorted by the criteria type is shown in Table 1. Land elevation is one of the most significant agroecological factors for hazel (Mirotadze et al., 2008). It was chosen as a primary topographic factor, alongside insolation and wind indicators, derived from elevation data. The average minimal air temperature in January (budding period) and the average mean air temperature in February (flowering period) were selected as critical for successful annual yield (Vujević et al., 2014). Rainfall amount was expanded to an entire year average, due to hazel being a permanent crop. Existing soil cultivation suitability classes were selected as an all-around indicator of suitability regarding the soil. Last selected factor is distance to nearest roads, since hazel plantation proximity from stationed agricultural machinery has an effect on logistical planning for conducting agrotechnical measures. Ecologically protected area was selected as an only constraint in the process of multicriteria analysis.

GIS software used in this study was SAGA GIS 7.2.0 for spatial modelling, calculation and geostatistics, alongside OGIS 3.4.5 for data visualization. Preformed spatial analysis is raster-based so all input vector criteria layers were rasterized, aside from constraint layer. All GIS layers are also reprojected to Croatian Terrestrial Reference System (HTRS96/TM), due to its prerequisite to be georeferenced in uniform coordinate reference system and projection. Spatial resolution of created layers and resulting suitability layer is 30 meters.

Table 1. Criteria for hazel plantation suitability analysis

Tablica 1. Kriteriji za analizu pogodnosti nasada lijeske

\begin{tabular}{|l|c|c|}
\hline $\begin{array}{l}\text { Criteria Name } \\
\text { Naziv } \text { kriterija }\end{array}$ & $\begin{array}{c}\text { Description } \\
\text { Opis }\end{array}$ & $\begin{array}{c}\text { Criteria Type } \\
\text { Vrsta } \text { kriterija }\end{array}$ \\
\hline Elevation & Digital elevation model & Factor \\
\hline Total Insolation & Potential annual total insolation & Factor \\
\hline Wind Exposition & Wind exposure index & Factor \\
\hline Rainfall & Average annual rainfall amount & Factor \\
\hline Min T January & Average January minimal air temperature & Factor \\
\hline Mean T February & Average February mean air temperature & Factor \\
\hline Soil Suitability & Soil map suitability classes for agriculture & Factor \\
\hline Road Distance & Distance to nearest road & Constraint \\
\hline Protected Area & Area restricted for agriculture by Republic of Croatia & \\
\hline
\end{tabular}

Four main data sources alongside constrained ecological area were used for the modelling of GIS layers. Shuttle Radar Topography Mission (SRTM) 1-arc second digital elevation model (DEM) was preprocessed and further used for calculation of insolation and wind exposition layers. Total insolation was calculated for time period between January 1, 2017 and December 31, 2017, with daily resolution of seven days and hourly resolution of four hours per day. It represents a sum of direct and diffuse potential insolation. Wind exposition index was calculated with the angular step size of 15 degrees. Air temperature and rainfall layers were interpolated using World Weather Online historical climate data from 2013 to 2017 (https://www.worldweatheronline.com/) for eight meteo stations located evenly around the study area. They are located in Slavonski Brod, Osijek, Županja, Vukovar, 
Gradačac, Bijelijina, Sombor and Novi Sad. Geostatistical method for interpolation was Inverse Distance Weighting (IDW) method, applied for climate data in various studies (Lofgren and Zhu, 2000; Xavier et al., 2016). Soil suitability was extracted from soil map 1:50000 (Bogunović et al., 1997), with suitability classes representing water or built-up areas (0), soil unsuitable for cultivation (N1, N2) and suitable for cultivation (P1, P2, P3). Road distance values mark horizontal distance to nearest paved road. Calculation was performed referring to Open Street Map vector data with highway attributes "primary", "second- ary" and "tertiary". All eight input factors layers are visualized on Figure 1. Finally, constraint layer consists of Spačvanski bazen with $382 \mathrm{~km}^{2}$ coverage, which represents NATURA 2000 ecologically protected area. For all layers representing the factors, values were reclassified to 5 classes in 1-5 number interval to indicate the degree of suitability of the specific factor. Such process is based on stepwise standardization method (Rahman et al., 2012). Border values for each class were created based on the optimal agroecological conditions for hazel cultivation on the study area (Krpina, 2004; Šoškić, 2006).

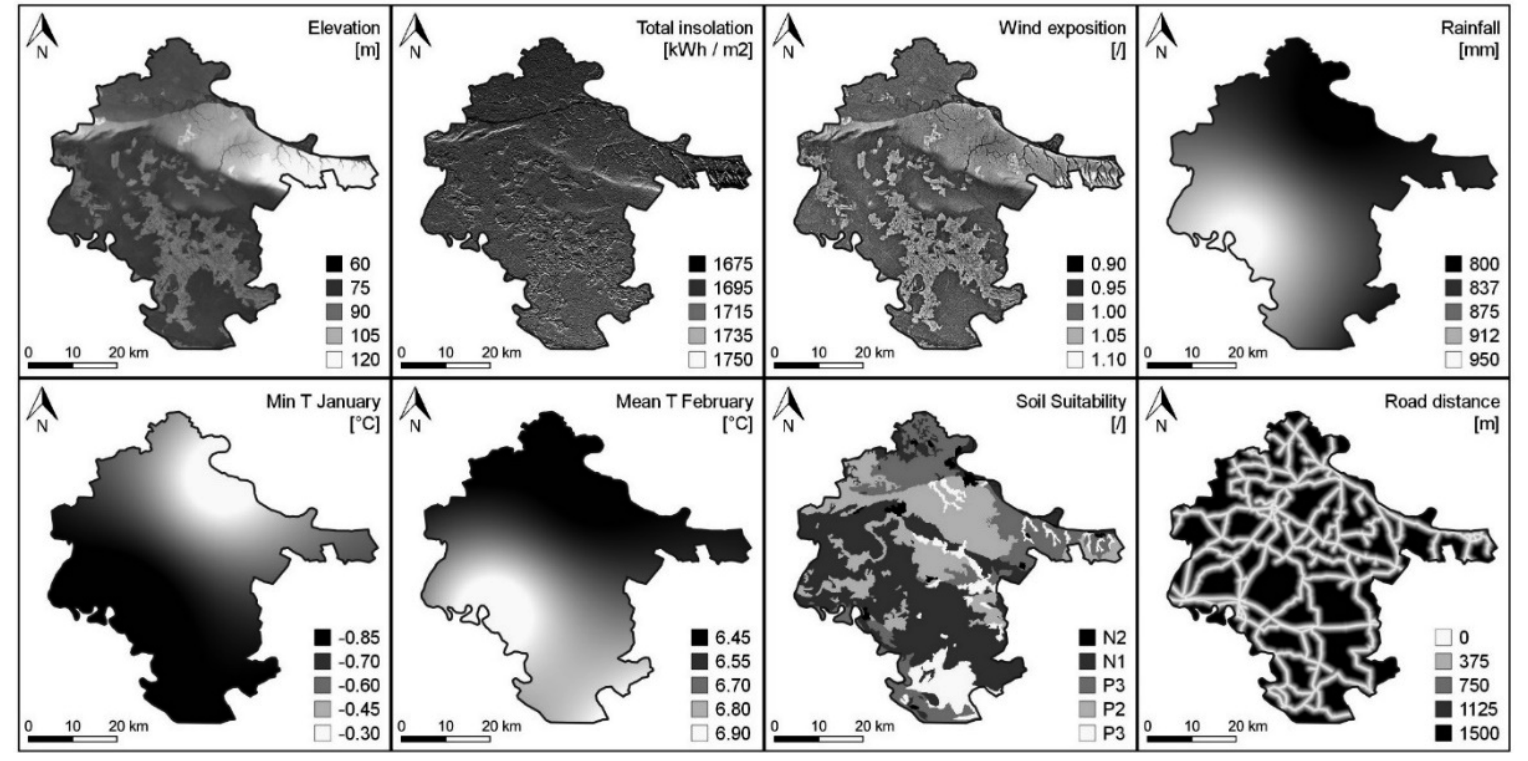

Figure 1. Input factor layers

Slika 1. Ulazni vrednujući slojevi

Computation of factor weights was conducted using the Analytic Hierarchy Process (AHP) method (Saaty, 2008). AHP is considered as the most suitable method for multicriteria decision analysis in most cases and is regarded as flexible, comprehensive and straightforward (Musakwa, 2017). Weights were calculated based on the pairwise comparison matrix, where each parameter (factor or factor group) is compared to every other parameter in matrix, based on their relative importance on hazel plantation suitability. Comparison ratings ranged from 1 (equally preferred) to 9 (extremely preferred). The comparisons were tested for inconsistency using the Consistency Ratio $(C R)$. It was calculated from the deviation of consistency shown through the Consistency Index $(C /)$, and the Random Consistency Index $(R /)$, an average $\mathrm{Cl}$ from a random matrix (Saaty, 2008):

$$
\begin{aligned}
& C R=\frac{C I}{R I}, \\
& C I=\frac{\lambda-n}{n-1},
\end{aligned}
$$

where $\lambda$ is average value of consistency vector and $n$ is the number of parameters. An acceptable value of inconsistency is 0.10 , whereas larger values indicate a necessity for revision of the pairwise comparisons (Zahedi, 1986; Saaty, 2008). Standardised factor values and their respective weights were combined by means of weighted linear combination for suitability calculation. Such procedure is one of the most often used decision models in GIS (Malczewski, 2000). The result was then intersected by the Boolean constraint vector layer, excluding the area permanently non-suitable for hazel cultivation from the result. Suitability was calculated following the formula (Eastman et al., 1995):

suitability $=\sum w_{i} X_{i} \cdot C$,

where $w_{i}$ is weight of factor $i, X_{i}$ is standardized values of factor $i$ and $C$ is Boolean layer of constraints.

\section{RESULTS AND DISCUSSION}

Values for reclassification of factor values during stepwise standardization are shown in Table 2. 
Table 2. Factor standardization classes

Tablica 2. Razredi standardizacije vrednujućih kriterija

\begin{tabular}{|c|c|c|c|c|c|}
\hline \multirow{2}{*}{$\begin{array}{c}\text { Factor Name } \\
\text { Naziv faktora }\end{array}$} & \multicolumn{5}{|c|}{$\begin{array}{c}\text { Standardized values } \\
\text { Standardizirane vrijednosti }\end{array}$} \\
\cline { 2 - 6 } & 1 & 2 & 3 & 4 & $150>$ \\
\hline Elevation [m] & $<60$ & $60-80$ & $80-100$ & $100-150$ & $1750>$ \\
\hline Total Insolation [kWh/m2 per year] & $<1675$ & $1675-1700$ & $1700-1725$ & $1725-1750$ & $1.05>$ \\
\hline Wind Exposition [/] & $<0.8$ & $0.8-0.9$ & $0.9-1.0$ & $1.0-1.05$ & $950>$ \\
\hline Rainfall [mm] & $<800$ & $800-850$ & $850-900$ & $900-950$ & $-0.3>$ \\
\hline Min T January [ $\left.{ }^{\circ} \mathrm{C}\right]$ & $<-0.85$ & $-0.85-(-0.6)$ & $-0.6-(-0.45)$ & $-0.45-(-0.3)$ & $6.90>$ \\
\hline Mean T February [ $\left.{ }^{\circ} \mathrm{C}\right]$ & $<6.45$ & $6.45-6.60$ & $6.60-6.75$ & $6.75-6.90$ & $\mathrm{P} 1$ \\
\hline Soil Suitability & $\mathrm{N} 2$ & $\mathrm{~N} 1$ & $\mathrm{P} 3$ & $\mathrm{P} 2$ & $<100$ \\
\hline Road Distance $[\mathrm{m}]$ & $1500>$ & $1000-1500$ & $500-1000$ & $100-500$ & $<100$ \\
\hline
\end{tabular}

Linear scaling method in $[0,1]$ interval was taken into strong consideration for standardization, being the one of the most used procedures (Malczewski, 1999). However, stepwise standardization method proved to be more useful than traditional linear scaling, due to the presence of extreme values on Elevation, Total Insolation, Wind Exposition and Road Distance layers (Figure 2). These values were detected as outliers in the process of boxplot creation. The presence of extreme values stretched the standardization interval and allowed the standardization to effectively use only about $20-50 \%$ of the number interval. Such process led to the creation of layers with dominant top or bottom values, which had a negative effect on suitability in further process. The creation of custom standardization classes avoided these effects and enabled higher level of agricultural expertise influence on the result.

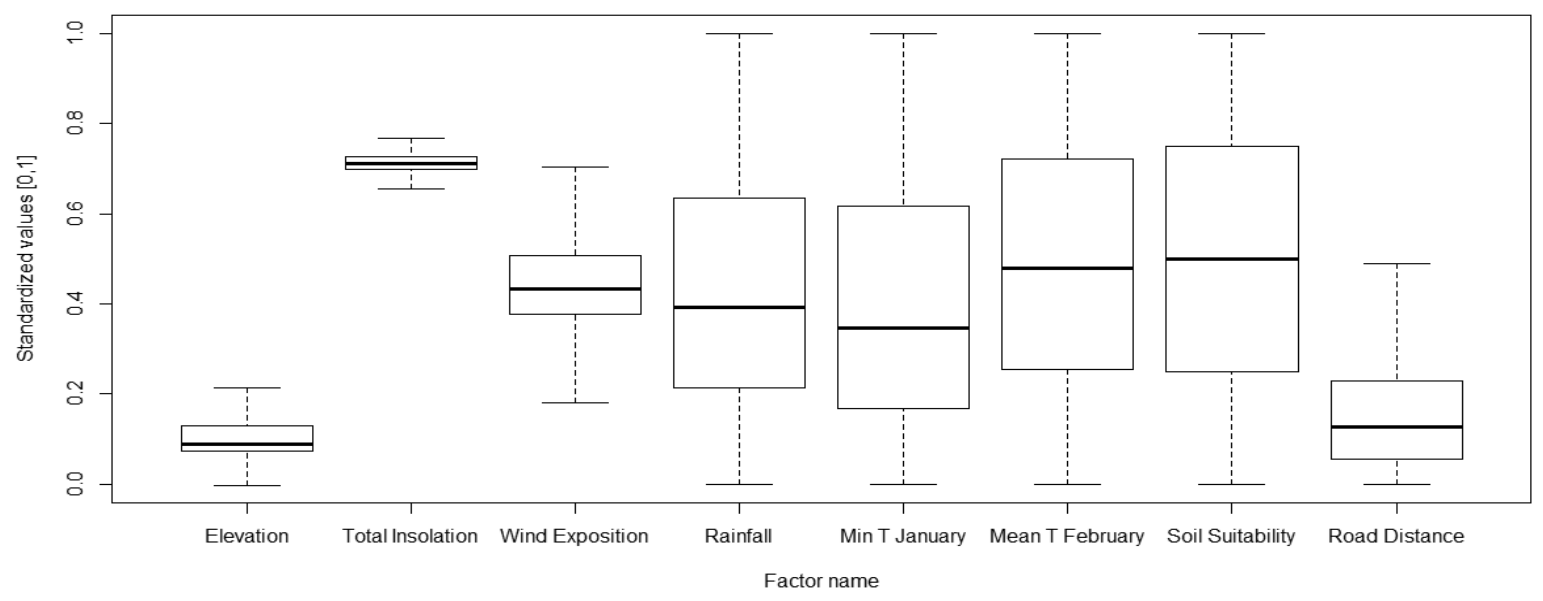

Figure 2. Boxplots of standardized values by linear scaling

Slika 2. Kutijasti dijagrami standardiziranih vrijednosti linearnim skaliranjem

Due to a high amount of chosen individual factors for AHP method, the factors with similar thematic characteristics were divided into factor groups. Elevation, Total Insolation and Wind Exposition were selected for the Topology group, whereas Climate group consisted of Rainfall, Min T January and Mean T February. Similarly, Soil Suitability factor was allocated to Pedology and Road Distance to Infrastructure group. First pairwise comparison was conducted on factor groups (Table 3), followed by the same procedure for factors in Topology (Table 4) and Climate factor group (Table 5). Maximum $\mathrm{RI}$ value amounts to 0.53 for three parameters and 0.90 for four parameters in pairwise comparison matrix (Saaty, 2008). CR values were lower than 0.10 for all three matrices, indicating a strong consistency in weights calculation. 
Table 3. Criteria groups pairwise comparison matrix

Tablica 3. Matrica usporedbe parova skupina kriterija

\begin{tabular}{|c|c|c|c|c|}
\hline & Topology & Climate & Pedology & Infrastructure \\
\hline Topology & 1 & 3 & 4 & 7 \\
\hline Climate & $1 / 3$ & 1 & 2 & 4 \\
\hline Pedology & $1 / 4$ & $1 / 2$ & 1 & 3 \\
\hline Infrastructure & $1 / 7$ & $1 / 4$ & $1 / 3$ & 1 \\
\hline
\end{tabular}

$\mathrm{Cl}=0.028 ; \mathrm{CR}=0.031<0.100$

Table 4. Pairwise comparison matrix for Topology criteria group

Tablica 4. Matrica usporedbe parova za topološku skupinu kriterija

\begin{tabular}{|l|c|c|c|}
\hline & Elevation & Insolation & Wind Exposition \\
\hline Elevation & 1 & 4 & 2 \\
\hline Total Insolation & $1 / 4$ & 1 & 1 \\
\hline Wind Exposition & $1 / 6$ & $1 / 2$ & 2 \\
\hline
\end{tabular}

$\mathrm{Cl}=0.007 ; \mathrm{CR}=0.013<0.100$

Table 5. Pairwise comparison matrix for Climate criteria group

Tablica 5. Matrica usporedbe parova za klimatsku skupinu kriterija

\begin{tabular}{|l|c|c|c|}
\hline & Rainfall & Min T January & Mean T February \\
\hline Rainfall & 1 & 2 & 3 \\
\hline Min T January & $1 / 3$ & 1 & 2 \\
\hline Mean T February & $1 / 2$ & $1 / 2$ & 1 \\
\hline
\end{tabular}

$\mathrm{Cl}=0.006 ; \mathrm{CR}=0.010<0.100$

Calculated group and individual weights are shown in Table 6. Total weights represent the product of individual weight with corresponding group weight. Sum of all total weights amounts to 1 , according to recom-

mendations of the AHP method. Elevation had the highest weight of all factors, with almost $40 \%$ influence on suitability result.

Table 6. Calculation of total factor weights

Tablica 6. Izračun ukupnih težina vrednujućih kriterija

\begin{tabular}{|l|c|c|c|c|}
\hline $\begin{array}{l}\text { Criteria group } \\
\text { Skupina kriterija }\end{array}$ & $\begin{array}{c}\text { Group weight } \\
\text { Težina skupine }\end{array}$ & $\begin{array}{c}\text { Individual criteria } \\
\text { Pojedinačni kriteriji }\end{array}$ & $\begin{array}{c}\text { Individual weight } \\
\text { Pojedinačna težina }\end{array}$ & $\begin{array}{c}\text { Total weight } \\
\text { Ukupna težina }\end{array}$ \\
\hline \multirow{3}{*}{ Topology } & \multirow{3}{*}{0.556} & Elevation & 0.700 & 0.389 \\
\cline { 3 - 5 } & & Total Insolation & 0.194 & 0.108 \\
\cline { 3 - 5 } & \multirow{3}{*}{ Climate } & Wind Exposition & 0.106 & 0.059 \\
\cline { 3 - 5 } & \multirow{3}{*}{0.236} & Rainfall & 0.539 & 0.127 \\
\cline { 3 - 5 } Pedology & & Min T January & 0.297 & 0.070 \\
\hline Infrastructure & 0.146 & Mean T February & 0.164 & 0.039 \\
\hline
\end{tabular}

Weighted linear combination was conducted in two steps: first consisting of multiplication of standardized layers with corresponding weights and their sum for entire study area and second where the constrained area was excluded from the suitability layer. Final suitability layer in form of thematic map is shown in Figure 3. Possible suitability values match standardization interval
[1-5], with mean suitability value of 2.86 and standard deviation of 0.37 . Suitability values range from 1.78 to 4.10 , which indicates that no part of the study area fully satisfies the selected criteria. Highest suitability values were present in eastern part of the County, in the City of llok neighbourhood. 


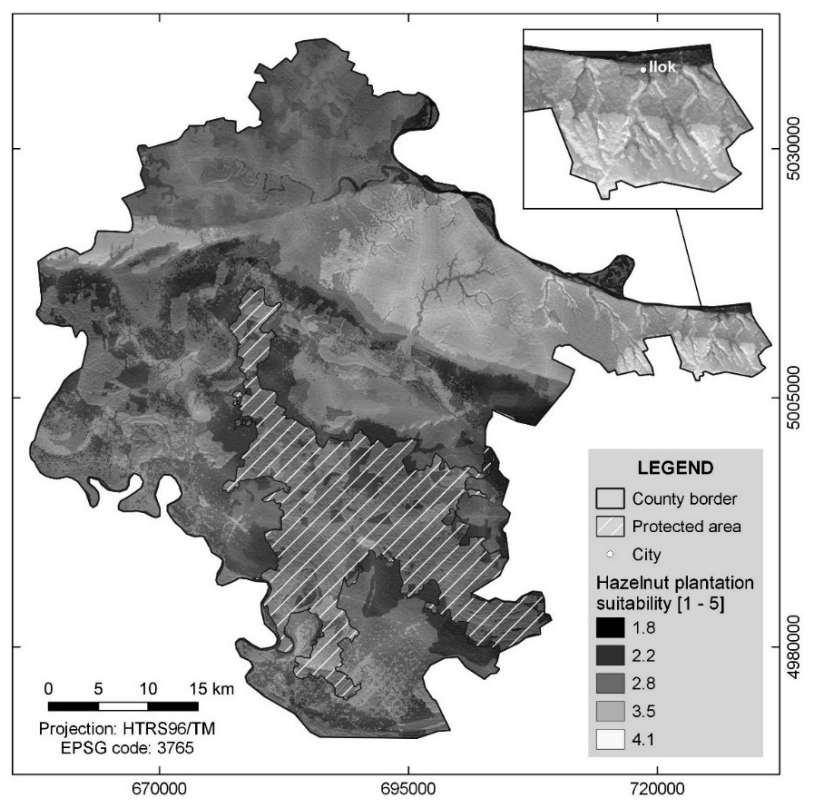

Figure 3. Suitability thematic map for hazelnut cultivation

Slika 3. Tematska karta pogodnosti uzgoja lijeske

\section{CONCLUSION}

Presented methodology enabled the evaluation of topographic, climate, pedological and infrastructural resources for suitability estimation for hazel plantations in Vukovar-Srijem County. The foundation of this procedure was GIS-based multicriteria analysis, which served as an integration tool of layers representing criteria and their respective weights. Multicriteria analysis provided a tool for modelling through calculation of cultivation suitability, enabling farmer to choose the most suitable area for plantation establishment. It also enables a farmer to utilize stationary topographic and climate properties of agricultural land by deciding how and when to implement agrotechnical measures in order to maximise its potential. The stepwise standardization method in $[1,5]$ interval was proven to be more effective than the traditional linear scaling method, due to the presence of extreme values in certain layers. Grouping of factors into four factor groups reduced the complexity of weight determination and enabled time-effective calculation. Elevation layer emerged as the most influential factor in the process. Standardized data and weights were integrated using weighted linear combination, resulting with suitability values ranging from 1.78 to 4.10 . The area around the City of llok resulted in the highest suitability, followed by north-eastern part of County near the Danube River. The suitability result was represented in the form of a thematic map, enabling the farmers to interpret the results without a need for extensive GIS knowledge.

\section{REFERENCES}

1. Bogunović, M., Vidaček, Ž., Racz, Z., Husnjak, S., \& Sraka, M. (1997). The practical aspects of soil suitability map of Croatia. Agronomski glasnik, 59(5-6), 363-399.

2. Bogunović, I., Đekmeti, I., Magdić, I., Vrbanić, M., Matošić, S., \& Mesić, M. (2016). Spatial modelling for describing spatial variability of soil physical properties in eastern Croatia. Poljoprivreda, 22(1), 46-52. https://doi.org/10.18047/poljo.22.1.7

3. Eastman, J. R., Jin, W., Kyem, P., \& Toledano, J. (1995). Raster procedures for multiobjective land-use planning. Photogrammetric Engineering and Remote Sensing, 61, 539-547.

4. Hayashi, K. (2000). Multicriteria analysis for agricultural resource management: a critical survey and future perspectives. European Journal of Operational Research, 122(2), 486-500.

https://doi.org/10.1016/S0377-2217(99)00249-0

5. Jurišić, M., \& Plaščak, I. (2009). Geoinformacijski sustavi GIS u poljoprivredi i zaštiti okoliša [Geoinformation systems GIS in agriculture and environment protection]. Osijek: Faculty of agriculture Osijek.

6. Jurišić, M., Frangeš, S., Plaščak, I., \& Šiljeg, A. (2013). Methodology of Development of Purpose Maps in GIS Environment-Resource Management. Geodetski list, 67(1), 1-12.

7. Jurišić, M., Plaščak, I., \& Jurić, T. (2013b). Methodology to develop land capability maps using geo-information systems (GIS). African Journal of Agricultural Research, 8(16), 1354-1360. https://doi.org/10.5897/AJAR11.766

8. Jurišić, M., Plaščak, I., Zimmer, D., Barač, Ž., \& Rapčan, I. (2018). Modern Navigation System DGPS as a Function of Saving in Agriculture. Tehnički vjesnik, 25(4), 1067-1074. https://doi.org/10.17559/TV-20170223094621

9. Kihoro, J., Bosco, N. J., \& Murage, H. (2013). Suitability analysis for rice growing sites using a multicriteria evaluation and GIS approach in great Mwea region, Kenya. SpringerPlus, 2(1), 265. https://doi.org/10.1186/2193-1801-2-265

10. Krpina, I. (2004). Voćarstvo [Fruit production]. Zagreb: Nakladni zavod Globus.

11. Lake, J. V., Bock, G. R., \& Goode, J. A. (Eds.). (2008). Precision agriculture: spatial and temporal variability of environmental quality (Vol. 210). New York: John Wiley \& Sons.

https://doi.org/10.1002/9780470515419.ch2

12. Lofgren, B. M., \& Zhu, Y. (2000). Surface energy fluxes on the Great Lakes based on satellite-observed surface temperatures 1992 to 1995. Journal of Great Lakes Research, 26(3), 305-314. https://doi.org/10.1016/S0380-1330(00)70694-0

13. Malczewski, J. (1999). GIS and multicriteria decision analysis. New York: John Wiley \& Sons. https://doi.org/10.1111/j.1538-4632.2002.tb01077.x

14. Malczewski, J. (2000). On the use of weighted linear combination method in GIS: common and best practice approaches. Transactions in GIS, 4(1), 5-22. https://doi.org/10.1111/1467-9671.00035 
15. Mirotadze, N., Gogitidze, V., Mikadze, N., Goginava, L., \& Mirotadze, M. (2008, June). Agro-ecological zones of hazelnut in Georgia. In VII International Congress on Hazelnut 845 (pp. 291-294).

https://doi.org/10.17660/ActaHortic.2009.845.43

16. Musakwa, W. (2017). Identifying land suitable for agricultural land reform using GIS-MCDA in South Africa. Environment, Development and Sustainability, 20(5), 2281-2299.

https://doi.org/10.1007/s10668-017-9989-6

17. Rahman, M. A., Rusteberg, B., Gogu, R. C., Ferreira, J. L., \& Sauter, M. (2012). A new spatial multi-criteria decision support tool for site selection for implementation of managed aquifer recharge. Journal of environmental management, 99, 61-75.

https://doi.org/10.1016/j.jenvman.2012.01.003

18. Saaty, T. L. (2008). Decision making with the analytic hierarchy process. International journal of services sciences, $1(1)$, 83-98.

https://doi.org/10.1504/IJSSCI.2008.017590

19. Sarkar, A., Ghosh, A., \& Banik, P. (2014). Multi-criteria land evaluation for suitability analysis of wheat: a case study of a watershed in eastern plateau region, India. Geo-Spatial Information Science, 17(2), 119-128. https://doi.org/10.1080/10095020.2013.774106

20. Seelan, S. K., Laguette, S., Casady, G. M., \& Seielstad, G. A. (2003). Remote sensing applications for precision agriculture: A learning community approach. Remote Sensing of Environment, 88(1-2), 157-169. https://doi.org/10.1016/j.rse.2003.04.007
21. Šoškić, M. (2006). Orah i lijeska [Walnut and hazel]. Bjelovar: Neron.

22. Vujević, P., Milinović, B., Vujević, B., Poljak, M., \& Čmelik, Z. (2014). Flowering period of hazel cultivars and dihogamy incidence in agro-ecological conditions of continental Croatia. Pomologia Croatica: Glasilo Hrvatskog agronomskog društva, 20(1-4), 3-10.

23. Vukadinović, V., Bertić, B., Đurđević, B., Vukadinović, V., Jug, I., \& Kraljičak, Ž. (2011). Analysis of land resources suitability by functional model in eastern Croatia region. Poljoprivreda, 17(1), 64-68.

24. Vukovar-Srijem County. (2017). Protection programme of air, ozone layer, reduction of climate changes and adaptation on climate changes for Vukovar-Srijem County. Retrieved from http://www.vusz.hr/Cms Data/Contents/VSZ/Folders/dokumenti/upravni8/ informacije/ contents/VDSJ23C6LGCKP4DW/nacrtprijedloga-programa-za-tite-zraka--ozonskog-sloja--ublavanja-klimatskih-promjena-i-prilagodbe-klimatskimpromjenama-za-podru-je-vs-.pdf

25. Vukovar-Srijem County. (2018). Development Strategy of Vukovar-Srijem County for time period until 2020. Retrieved from https://www.vusz.hr/Cms_Data/ Contents/VSZ/Folders/dokumenti/upravni2/ contents/ Y482ECCDYBAFDZM2/rv-razvojna-strategija-vs-01-03-18---s-analiza-stanja-sa-etaksvd1.pdf

26. Xavier, A. C., King, C. W., \& Scanlon, B. R. (2016) Daily gridded meteorological variables in Brazil (19802013). International Journal of Climatology, 36(6), 26442659.

https://doi.org/10.1002/joc.4518

\section{PLANIRANJE NASADA LIJESKE UPORABOM GIS-A I MULTIKRITERIJSKE ANALIZE}

\section{SAŽETAK}

Poljoprivredno je zemljište stacionarna komponenta s prostornim i ekološkim uvjetima na koje se ne može utjecati, kao što su topografija i klima. Provedeno istraživanje predstavlja metodologiju za izračun pogodnosti nasada lijeske temeljenu na multikriterijskoj analizi i primijenjenu u Vukovarsko-srijemskoj županiji. Devet kriterija koji predstavljaju topografska, klimatska, pedološka i infrastrukturna svojstva modelirana su u GIS okruženju. Vrijednosti stvorenih slojeva standardizirane su pomoću postupne standardizacije, a njihove težine izračunate su analitičkim hijerarhijskim procesom. Te su vrijednosti integrirane pomoću težinske linearne kombinacije, što je rezultiralo vrijednostima pogodnosti. Područje najviše pogodnosti za nasade lijeske na području istraživanja okolica je grada lloka, s maksimalnom prikladnošću 4,1 od mogućih 5,0. Razina pogodnosti vizualizirana je u obliku tematske karte, koja omogućuje poljoprivrednicima interpretaciju podataka.

\section{Ključne riječi: multikriterijska analiza, GIS, tematska karta, AHP, lijeska}

(Received on July 3, 2019; accepted on November 20, 2019 - Primljeno 3. srpnja 2019.; prihvaćeno 20. studenoga 2019.) 
